\title{
Absorption of macronutrients by cassava in different harvest dates and dosages of nitrogen ${ }^{1}$
}

\author{
Absorção de macronutrientes pela mandioca em diferentes épocas de colheita e doses \\ de nitrogênio
}

\author{
Nádia Souza dos Santos ${ }^{2 *}$, José Maria Arcanjo Alves ${ }^{3}$, Sandra Catia Pereira Uchôa ${ }^{4}$, Natália Trajano de Oliveira ${ }^{2}$ \\ e José de Anchieta Alves de Albuquerque ${ }^{3}$
}

\begin{abstract}
A field experiment was carried out in 2010-2011 crop years in the experimental area of the Centro de Ciências Agrárias of the Universidade Federal de Roraima, in Boa Vista, Roraima, Brazil. This study aimed to evaluate the effect of nitrogen availability on the concentrations of $\mathrm{N}, \mathrm{P}, \mathrm{K}, \mathrm{Ca}, \mathrm{Mg}$ and $\mathrm{S}$ in cassava, cultivar Aciolina, in different harvest times. A randomized block design was used in split-plot, with four replications. Dosages of $\mathrm{N}$ in cover were applied randomly on the plots $\left(0,30,60,150\right.$ and $\left.330 \mathrm{~kg} \mathrm{ha}^{-1}\right)$, and in the subplot the harvest dates $120,150,180$, 210, 240, 270 and 300 days after emergence (DAE). The vegetal material was collected, ground and then underwent an analysis for determination of nutrients concentrations in the leaves ( $, \mathrm{P}, \mathrm{K}, \mathrm{Ca} \mathrm{Mg}$ and $\mathrm{S}$ ). The harvest dates and dosages of $\mathrm{N}$ affect the nutrient concentrations in the cassava leaves, cv. Aciolina. The macronutrients dosage in the

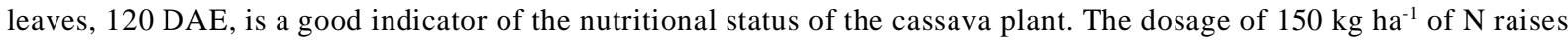
the tubers roots per plant. The sequence of the macronutrients concentration in the leaves of the cassava, cv. Aciolina is $\mathrm{N}>\mathrm{Ca}>\mathrm{K}>\mathrm{Mg}>\mathrm{P}>\mathrm{S}$.
\end{abstract}

Key words: Fertilisation. Manihot esculenta. Plants-Nutrition. Plants-Nitrogen effect.

RESUMO - Um experimento de campo foi conduzido entre os anos agrícolas de 2010 e 2011 na área experimental do Centro de Ciências Agrárias da Universidade Federal de Roraima em Boa Vista, Roraima, Brasil. Objetivou-se com este trabalho avaliar o efeito de doses de nitrogênio no teor de N, P, K, Ca, Mg e S na mandioca, cultivar Aciolina, em diferentes épocas de colheita. O delineamento experimental adotado foi em blocos casualizados em parcelas subdividas, com quatro repetições. Nas parcelas foram aleatorizadas as doses de $\mathrm{N}$ em cobertura $\left(0 ; 30 ; 60 ; 150\right.$ e $\left.330 \mathrm{~kg} \mathrm{ha}^{-1}\right) \mathrm{e}$ nas subparcelas as épocas de avaliação 120;150; 180;210;240; 270 e 300 dias após a emergência das plantas (DAE). O material vegetal coletado foi moído e, posteriormente, submetido à análise para obtenção dos teores de nutrientes nas folhas (N, P, K, Ca, Mg e S). As épocas de avaliação e as doses de $\mathrm{N}$ afetam os teores dos macronutrientes na folha da mandioca, cv. Aciolina. A dosagem dos macronutrientes na folha, aos 120 DAE, é um bom indicador do estado nutricional da planta de mandioca. A dose de $150 \mathrm{~kg} \mathrm{ha}^{-1}$ de $\mathrm{N}$ determina o maior rendimento de raiz por planta de mandioca. A concentração dos nutrientes na folha da mandioca, cv. Aciolina, é $\mathrm{N}>\mathrm{Ca}>\mathrm{K}>\mathrm{Mg}>\mathrm{P}>\mathrm{S}$.

Palavras-chave: Adubação. Manihot esculenta. Plantas-Nutrição. Plantas-efeito do nitrogênio.

\footnotetext{
*Autor para correspondência

${ }^{1}$ Recebido para publicação em 21/09/2013; aprovado em 15/04/2014

Trabalho extraído da Dissertação do primeiro autor apresentada ao Programa de Pós-Graduação em Agronomia/POSAGRO, Universidade Federal de Roraima/UFRR

${ }^{2}$ Programa de Pós-Graduação em Agronomia/UFRR, BR 174, Campus Cauamé, Monte Cristo, Boa Vista-RO, Brasil, 69.300-000, nadia. ss.agro@hotmail.com, nataliatrajano@bol.com.br

${ }^{3}$ Departamento de Fitotecnia, Centro de Ciências Agrárias/UFRR, BR 174, Campus Cauamé, Monte Cristo, Boa Vista-RO, Brasil, 69.300-000, arcanjo.alves@ufrr.br, anchietaufrr@gmail.com

${ }^{4}$ Departamento de Solos e Engenharia Agrícola, Centro de Ciências Agrárias/UFRR, BR 174, Campus Cauamé, Monte Cristo, Boa Vista-RO, Brasil, 69.300-000, sandra.uchoa@ufrr.br
} 


\section{INTRODUCTION}

Cassava cultures (Manihot esculenta Crantz) are found in numerous regions worldwide because of its resistance to adverse climate and soil conditions. It is considered a complete plant, with roots rich in carbohydrates and leaves rich in proteins, vitamins $\mathrm{A}$ and $\mathrm{C}$, as well as other nutrients (FUKUDA, 2005). Production of cassava roots in Brazil in 2012 was $24,313,883 \mathrm{Mg}, 4.0 \%$ lower than the total produced in 2011 (INSTITUTO BRASILEIRO DE GEOGRAFIA E ESTATÍSTICA, 2013).

In Brazil, cassava is mainly directed to starch production, which is used in the most diverse industries (cosmetics, pharmaceuticals, food, among others), and is highly appreciated in the making of tapioca and cheese bread, traditional foods of the Brazilian cuisine. Cultivars of sweet cassava, identified by low levels of cyanogenic compounds and dietary fibers, high starch content and organoleptic characteristics, which yield flavor and cooking quality, are vegetables widely consumed in large urban centers in Brazil, marketed in natura, minimally processed or processed in the form of precooked, frozen and pasta foods (AGUIAR et al., 2011; VALLE et al., 2004).

Cassava grows and produces relatively well in low fertility soils, but there are clear evidences that they extract large amounts of nutrients from the soil and respond to soil fertilization with significant yield increases (AYOOLA; MAKINDE, 2007; CARDOSO JUNIOR et al., 2005; DEVIDE et al. 2009).

The chemical composition and accumulation of nutrients in the leaves are key information in the determination of the nutritional requirements of a plant. Leaf analysis is used to diagnose the plants' nutritional condition and is based on the fact that there is a direct relation between the growing rate and the levels of nutrients present in the leaf tissues. Thus, nutritional diagnosis along with soil analysis constitutes an effective instrument for detecting imbalances and assist in the plants' fertilization process (COELHO et al., 2010).

Despite the fact that the natural $\mathrm{N}$ supply in tropical soils is limited, most farmers do not apply nitrogen fertilization in cassava crops. This indicates that much of the cultivated land and the cassava growth and development take place under conditions of N deficiency, limiting their yield potential (CRUZ; PELACANI; ARAÚJO, 2006).

A major feature of nitrogen is its interaction with the absorption of other nutrients, which can be synergistic (positive) or antagonistic (negative). Parry et al. (2005), when assessing the plants' nutritional status at different times and subjected to leaf litter coverage and fertilization, found the following descending order of accumulation: $\mathrm{K}>\mathrm{N}>\mathrm{Ca}>\mathrm{Mg}>\mathrm{P}>\mathrm{S}>\mathrm{Cu}>\mathrm{Fe}>\mathrm{Mn}>\mathrm{Zn}>\mathrm{B}$.

Given the above, the present work aimed to assess the effect of nitrogen dosages on the levels of $\mathrm{N}, \mathrm{P}, \mathrm{K}$, $\mathrm{Ca}, \mathrm{Mg}$ and $\mathrm{S}$ in the cassava Aciolina cultivar at different harvest dates throughout the production cycle.

\section{MATERIAL AND METHODS}

The field experiment was conducted between October 2010 and August 2011 in the experimental area of the Campus Cauamé, Centro de Ciências Agrárias (Agricultural Center) - CCA/UFRR, in Boa Vista, State of Roraima - Brazil (Latitude 2 ${ }^{\circ} 52^{\prime} 20,7^{\prime}$ ' N, Longitude $60^{\circ} 42^{\prime} 44,2^{\prime \prime} \mathrm{W}$, mean altitude of $90 \mathrm{~m}$ ). According to Köppen classification, the climate corresponds to the Aw category, with two well-defined climate seasons, a rainy season (April-August) and a dry season (October-March). Figure 1 shows the climatic data observed during the experimental period relating to rainfall, mean temperature and relative air humidity (INSTITUTO NACIONAL DE METEREOLOGIA, 2012).

The soil of the experimental area was classified as Argisol Yellow distrocoeso (PAdx), sandy clay loam texture and slightly undulating relief. This soil is deep, well drained, with signs of laminar erosion, non-stony, non-rocky ground, and the dominant vegetation is of the savannah type (BENEDETTI et al., 2011). The implementation of the culture succeeded primary vegetation.

The physical and chemical analyses of the soil samples of the area under study, at a depth of 0-0.20 and 0.20-0.40 m, were carried out at the Soils Laboratory of the Universidade Federal de Viçosa - UFV, and the results are shown in Table 1.

Figure 1 - Monthly averages of rainfall, air temperature and relative air humidity in the period from October 2010 to August 2011. Boa Vista-RR

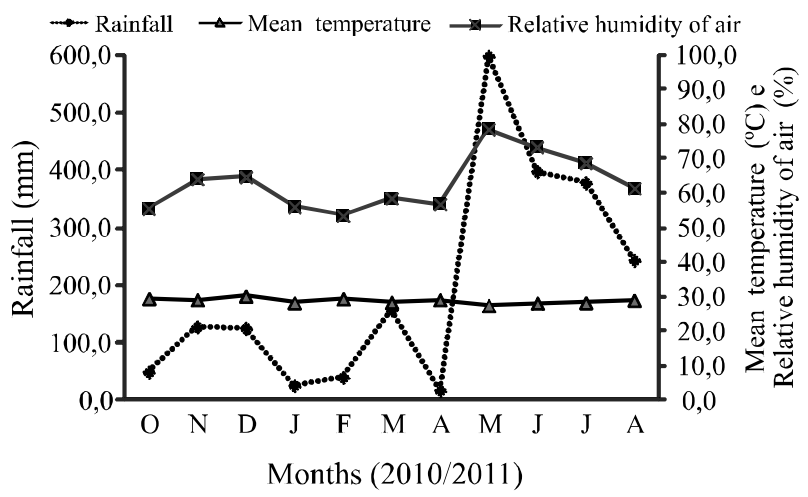


Table 1 - Physical and chemical characteristics of the soil at a depth of 0-0.20 and 0.20-0.40 m prior to the experiment implementation

\begin{tabular}{|c|c|c|c|c|c|c|c|c|c|c|c|c|c|}
\hline \multirow{2}{*}{ Layer } & \multirow{2}{*}{$\mathrm{pH} \mathrm{H}_{2} \mathrm{O}$} & $\mathrm{P}^{1 /}$ & $\mathrm{K}^{1 /}$ & $\mathrm{Ca}^{2 /}$ & $\mathrm{Mg}^{2 /}$ & $\mathrm{Al}^{2 /}$ & $\mathrm{H}+\mathrm{Al}^{3 /}$ & SB & CTCef & $\mathrm{T}$ & $\mathrm{V}$ & $\mathrm{m}$ & $\mathrm{MO}^{4 /}$ \\
\hline & & \multicolumn{2}{|c|}{$\mathrm{mg} \mathrm{dm}^{-3}$} & \multicolumn{7}{|c|}{ 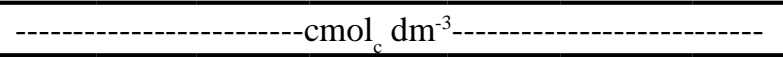 } & \multicolumn{2}{|c|}{$\%$} & $\mathrm{~g} \mathrm{~kg}^{-1}$ \\
\hline $0-0.20$ & 5.16 & 0.9 & 6.7 & 0.89 & 0.13 & 0.21 & 1.0 & 1.19 & 1.4 & 2.19 & 54.3 & 15 & 6.7 \\
\hline $0.20-0.40$ & 5.06 & 0.5 & 7.0 & 0.24 & 0.03 & 0.51 & 1.2 & 0.45 & 0.96 & 1.65 & 27.3 & 53.1 & 4.0 \\
\hline \multirow[t]{2}{*}{ Layer } & \multicolumn{3}{|c|}{ Coarse sand ${ }^{5 /}$} & \multicolumn{2}{|c|}{ Fine sand } & \multicolumn{2}{|c|}{ Silt } & \multicolumn{2}{|c|}{ Clay } & \multicolumn{4}{|c|}{ Textural class } \\
\hline & \multicolumn{13}{|c|}{ 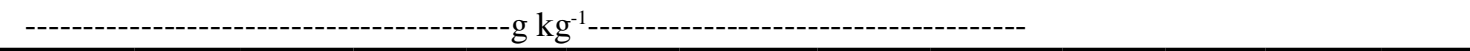 } \\
\hline $0-0.20$ & \multicolumn{3}{|c|}{410} & \multicolumn{2}{|l|}{300} & \multicolumn{2}{|c|}{70} & \multicolumn{2}{|c|}{220} & \multicolumn{4}{|c|}{ Sandy clay loam } \\
\hline $0.20-0.40$ & \multicolumn{2}{|c|}{360} & & \multicolumn{2}{|l|}{290} & \multicolumn{2}{|c|}{90} & \multicolumn{2}{|c|}{260} & \multicolumn{4}{|c|}{ Sandy clay loam } \\
\hline
\end{tabular}

${ }^{1 /}$ - Mehlich-1 extraction; ${ }^{2 /}$ - KCl $1 \mathrm{~mol} \mathrm{~L}{ }^{-1}$ extraction; ${ }^{3 /}$ Extraction of $0.5 \mathrm{~mol} \mathrm{~L}^{-1}$ Calcium Acetate; ${ }^{4 /}$ Organic matter (OM) of soil - WalkleyBlack method; pipette method (EMBRAPA, 1997)

The cassava cultivar used was Aciolina, belonging to the collection of Cassava Germplasm of the Department of Plant Science, CCA/UFRR, which is the most common cultivar grown in the state of Roraima because it has the best desirable characteristics, either for in natura consumption or for the industry, which explains its large production and marketing (ALVES et al., 2009; OLIVEIRA et al., 2011).

Experimental randomized blocks design was implemented with four replicates in subdivided plots, and five dosages of nitrogen were applied randomly onto the plot cover (urea source), and the nutrients concentrations in the leaves were determined at different days after emergence (DAE) for each subplot. Dosages of $\mathrm{N}\left(0,30,60,150\right.$ and $\left.330 \mathrm{~kg} \mathrm{ha}^{-1}\right)$ were applied in cover, and each dose was subdivided into two applications, 30 and 60 DAE. The soil was irrigated before and after application of the $\mathrm{N}$ doses. The dates of assessment constituted the subplots, being: 120, 150, 180, 210, 240, 270 and 300 DAE.

The experimental plot consisted of nine simple rows of planted cassava, $8.0 \mathrm{~m}$ long and $6.4 \mathrm{~m}$ wide, having 11 plants (total of 99 plants per plot) where the $4.8 \mathrm{~m}$ in the middle of the central rows corresponded to the usable area $\left(23.04 \mathrm{~m}^{2}\right)$.

Thirty days prior to planting, lime and fertilizer for soil correction were applied following the general recommendations of EMBRAPA-RR (SCHWENGBER; SMIDERLE; MATTIONI, 2005), being distributed broadcast and without incorporation throughout the experimental area: $1000 \mathrm{~kg} \mathrm{ha}^{-1}$ of dolomitic limestone (100\% PRNT), $90 \mathrm{~kg} \mathrm{ha}^{-1}$ of $\mathrm{P}_{2} \mathrm{O}_{5}$ (triple superphosphate), $60 \mathrm{~kg} \mathrm{ha}^{-1}$ of $\mathrm{K}_{2} \mathrm{O}$ (potassium chloride) and $30 \mathrm{~kg} \mathrm{ha}^{-1}$ of $\mathrm{N}$ (ammonium sulfate).

Ten days prior to planting, the natural vegetation was desiccated by a glyphosate-based herbicide. Planting was done in single rows, as recommended for monocrop cassava cultivation (ALBUQUERQUER et al., 2012), spacing of $0.8 \times 0.8 \mathrm{~m}$, and totaling 15,625 plants per hectare. Cassava cuttings measuring $20 \mathrm{~cm}$ long were planted horizontally in holes manually dug by hoe at a depth of approximately $10 \mathrm{~cm}$.

In the planting day the holes were complemented with dolomitic limestone (500 kg ha-1), $20 \mathrm{~kg} \mathrm{ha}^{-1}$ of $\mathrm{P}_{2} \mathrm{O}_{5}$ (simple superphosphate), $10 \mathrm{~kg} \mathrm{ha}^{-1}$ of $\mathrm{K}_{2} \mathrm{O}$ (potassium chloride) and $50 \mathrm{~kg} \mathrm{ha}^{-1}$ of FTE BR-12. The supplementary fertilization aimed to increase the availability of $\mathrm{Ca}, \mathrm{Mg}, \mathrm{P}$ and $\mathrm{K}$ in the root zone, considering its levels in the soil (Table1).

In the period from October 2010 to April 2011 conventional sprinkler performed supplementary irrigation. The soil moisture was measured by tensiometers placed at a depth of $0.20 \mathrm{~m}$ in six sites of the experimental area. Irrigation was initiated when the soil water tension was around $-20 \mathrm{kPa}$, and the area was irrigated with a flow rate of 3,000 L h-1 (Fabrimar ECO A320) three times a week.

During the experimental period manual weeding was performed to control weeds, taking into account the critical period for weed interference (30 to 75 days after emergence-DAE), according to Albuquerque et al. (2008).

For the foliar chemical analysis 10 leaves (without petiole) per plant from three plants in the useable area were collected from the apex (MARTINEZ; CARVALHO; SOUZA, 1999; RAIJ, 2011). The samples were rinsed in deionized water, dried in a forced-air oven at $70{ }^{\circ} \mathrm{C}$ for 72 hours, and ground. Total $\mathrm{N}$ content was determined by the Kjeldahl's method (MALAVOLTA et al., 1997). Contents of $\mathrm{P}, \mathrm{K}, \mathrm{Ca}, \mathrm{Mg}$ and $\mathrm{S}$ nutrients were determined after mineralization by nitric-perchloric $(2: 1)$ digestion. $\mathrm{P}$ content was determined by the method of phosphomolybdate reduction with vitamin $\mathrm{C}$. K content was determined by flame photometry absorption. Also, 
the roots growth per plant in a sample of three plants from the useable area at each day of assessment was determined. The average mass obtained was expressed in $\mathrm{kg}$ per plant.

The results were subjected to analysis of variance $(p<0.05)$ and regression for significant effects, using the SAEG statistical package. The coefficients of the components of each model were tested $(p<0.05)$, and the significant models with higher determination coefficient were chosen.

\section{RESULTS AND DISCUSSION}

According to the analysis of variance, the interaction between the $\mathrm{N}$ dosages and the harvest dates was significant for the variables studied. To determine the plant responses to the harvest dates at different levels of fertilization with $\mathrm{N}$, unfolding interaction was performed. Roots production per plant, $\mathrm{P}$ and $\mathrm{S}$ contents as a function of the harvest dates were described by linear model; $\mathrm{N}$ contents were described by cubic model, and $\mathrm{K}, \mathrm{Ca}$ and $\mathrm{Mg}$ contents by the quadratic model (Figure 2). The limits of sufficiency, as established by Raij (2011), were compared to the contents in leaves collected 120 DAE.

The leaf $\mathrm{N}$ content was modeled by cubic function (Figure 2a), an indication that during the cycle the plant had alternating periods of this nutrient in the leaves, 120 DAE, and in between 243 and 249 DAE, irrespective of $\mathrm{N}$ dosages. The leaf $\mathrm{N}$ levels ranged from 28.4 to $41.9 \mathrm{mg} \mathrm{kg}^{-1}$, $120 \mathrm{DAE}$, and from 33.0 to $42.6 \mathrm{mg} \mathrm{kg}^{-1}$ in the second period (243 to $249 \mathrm{DAE}$ ). On the 300 th DAE, $\mathrm{N}$ contents decreased in all $\mathrm{N}$ levels, ranging from 19.8 to $32.3 \mathrm{~g} \mathrm{~kg}^{-1}$, probably as a result of the translocation to other parts of the plant, including the roots.

Table 2 shows the levels of $\mathrm{N}, \mathrm{P}, \mathrm{K}, \mathrm{Ca}, \mathrm{Mg}$ and $\mathrm{S}$ and roots production per plant, as determined by estimated regression equations (Figure 2) for each $\mathrm{N}$ dosage 120 DAE. It could be seen that at this time, irrespective of the level of $\mathrm{N}$ fertilization, the leaf $\mathrm{N}$ levels were below the sufficiency range established by Raij (2011), i.e., from 45 to $60 \mathrm{~g} \mathrm{~kg}^{-1}$. Results for leaf $\mathrm{N}$ levels below such sufficiency standard level were observed by Parry et al. (2005). It is possible that the sufficiency level indicated in literature is vulnerable to environmental conditions and cultivars. Considering the roots production per plant as well as the sufficiency limit observed for $\mathrm{P}, \mathrm{K}, \mathrm{Ca}, \mathrm{Mg}$ and $\mathrm{S}$ contents, it can be suggested that $\mathrm{N}$ concentrations in the range of 30 and $60 \mathrm{~g} \mathrm{~kg}^{-1}$ are considered nutritionally sufficient for the Aciolina cultivar. Rodríguez et al. (2009) defined the concentration of $33 \mathrm{~g} \mathrm{~kg}^{-1}$ as appropriate for the foliar blade, based on the sufficiency limits established by Mills and Benton (1996).

The leaf $\mathrm{P}$ content was positively affected by the time of assessment and $\mathrm{N}$ dosages in the soil (Figure 2b). On the 120 th DAE, P concentrations in the leaves varied from 1.67 to $2.68 \mathrm{~g} \mathrm{~kg}^{-1}$ between the 0 and $333 \mathrm{~kg} \mathrm{ha}^{-1} \mathrm{~N}$ dosages (Table 2). The plants that received $\mathrm{N}$ cover in amounts greater than $30 \mathrm{~kg} \mathrm{ha}^{-1}$ showed $\mathrm{N}$ concentrations in the leaves within the limits of sufficiency established by Raij (2011), from 2 to $5 \mathrm{~g} \mathrm{~kg}^{-1}$. Studies conducted by Parry et al. (2005) in cassava subjected to two P dosages and four planting periods found that dosages and planting times had influence on the leaf $\mathrm{P}$ content, with concentrations ranging from 2.2 to $3.1 \mathrm{~g} \mathrm{~kg}^{-1}$. Rodríguez et al. (2009), when studying nutrients accumulation at different parts of cassava cultivar Tempranita, found that the average leaf $\mathrm{P}$ levels were of $2.5 \mathrm{~g} \mathrm{~kg}^{-1}$. These reports indicate that the variation in the $\mathrm{P}$ level found in the Aciolina cultivar is explained by the availability of $\mathrm{N}$, which affected positively the $\mathrm{P}$ uptake throughout the cultivation cycle.

The $\mathrm{P}$ behavior, modeled by linear function, can be explained by the greater development of absorbing roots, stimulated by the larger availability of $\mathrm{N}$ in the soil, thus increasing the explored crop area and, consequently, higher $\mathrm{P}$ uptake. The $\mathrm{P}$ uptake model is corroborated by the production of roots per plant that presented the linear model (Figure 2g). Linear response of cassava roots production as a function of a larger availability of $\mathrm{P}$ in the soil was observed by Pereira et al. (2012).

Leaf $\mathrm{K}$ content as a function of the assessment times was described by the quadratric model for all $\mathrm{N}$ dosages studied (Figure 2c). On the $120^{\text {th }}$ DAE, leaf K content varied from 11.99 to 13.76 among the $\mathrm{N}$ dosages probably because the plant was still in its initial stage, when the absorbing roots are formed, responsible for absorbing the nutrients from the soil, as reported by Alves (2006).

The maximum $\mathrm{K}$ concentration, $16.8 \mathrm{~g} \mathrm{~kg}^{-1}$, occurred with $\mathrm{N}$ dosage of $330 \mathrm{~kg} \mathrm{ha}^{-1}, 210$ DAE. On the other hand, the lowest concentration, $9.4 \mathrm{~g} \mathrm{~kg}^{-1}$, occurred with $\mathrm{N}$ dosage of $0 \mathrm{~kg} \mathrm{ha}^{-1}$ at 300 DAE. Leaf $\mathrm{K}$ concentration in Aciolina cultivar was maintained within the sufficiency range established by Raij (2011), of 10 to $20 \mathrm{~g} \mathrm{~kg}^{-1}, 120 \mathrm{DAE}$, as well as, on the other dates of assessment and for $\mathrm{N}$ dosages, except for the $\mathrm{N}$ dosage of $0 \mathrm{~kg} \mathrm{ha}^{-1}$ at $300 \mathrm{DAE}$. The planting dates and $\mathrm{P}$ dosages affected the leaf $\mathrm{K}$ contents in the cassava cultivar Olho Verde, with concentrations varying from 15.3 to $21.3 \mathrm{~g} \mathrm{~kg}^{-1}$ (PARRY et al., 2005). Studies conducted by Rodríguez et al. (2009) on the high plains of Maracaibo, Venezuela, on cultivar Tempranita, showed that the leaf was the part of the plant with the 
Figure 2 - Foliar contents of $\mathrm{N}$ (a), P (b), K (c), Ca (d), Mg (e), S (f), roots production (g) in cassava plants, Aciolina cultivar, according to the harvest dates, in the $\mathrm{N}$ levels. Boa Vista-RR
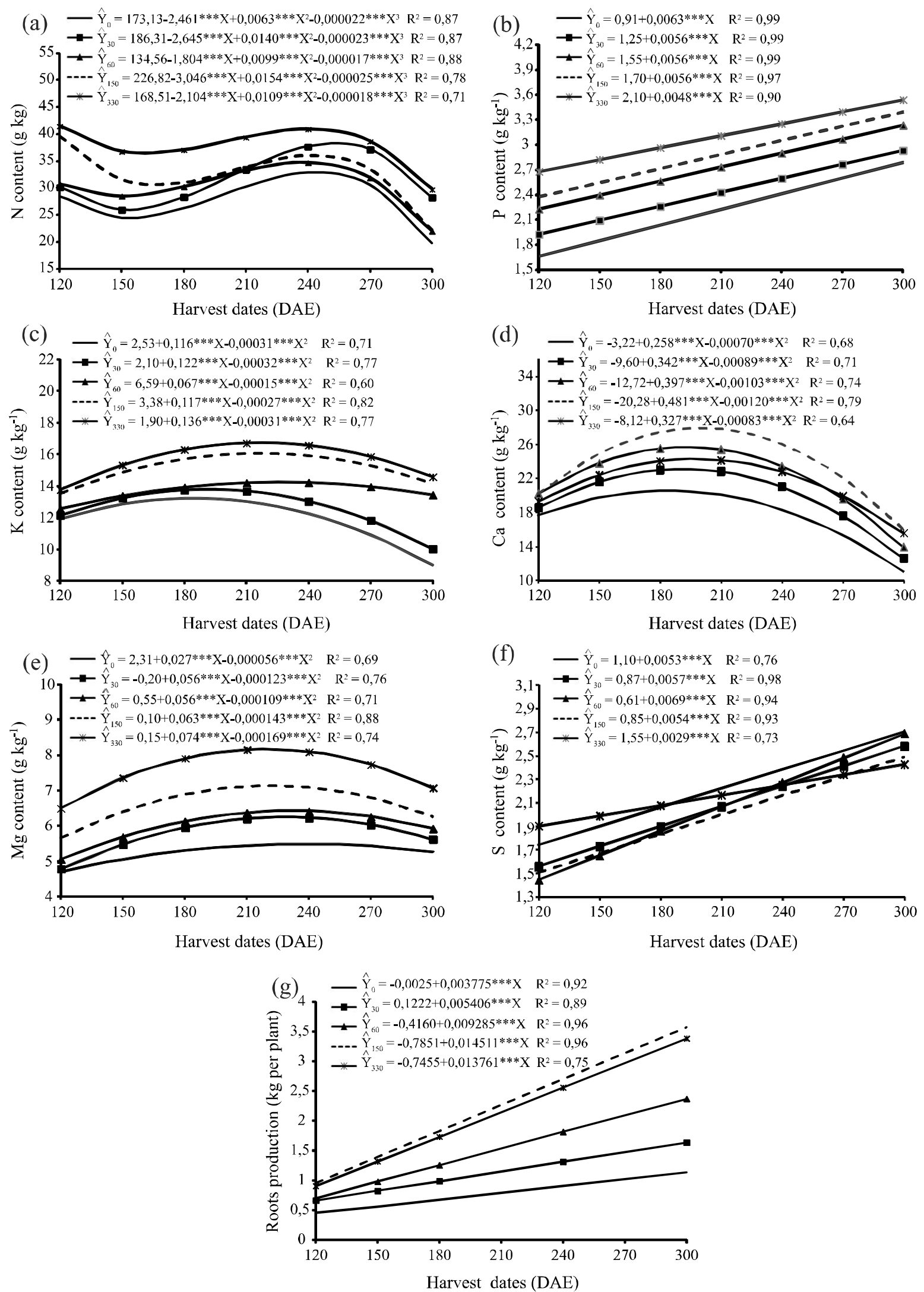
Table 2 - N, P, K, Ca and Mg contents in the leaves 120 DAE and roots production 300 DAE, for Aciolina cassava, with different N dosages

\begin{tabular}{|c|c|c|c|c|c|c|c|}
\hline \multirow{2}{*}{$\mathrm{N}$ dosage $\left(\mathrm{kg} \mathrm{ha}^{-1}\right)$} & \multicolumn{6}{|c|}{ 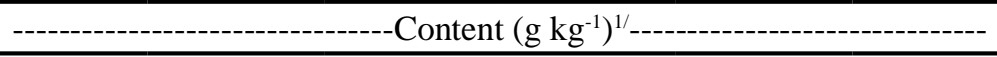 } & \multirow{2}{*}{ Prod. $^{2 /}$ (kg per plant) } \\
\hline & $\mathrm{N}$ & $\mathrm{P}$ & $\mathrm{K}$ & $\mathrm{Ca}$ & $\mathrm{Mg}$ & $\mathrm{S}$ & \\
\hline 0 & 28.4 & 1.67 & 11.99 & 17.66 & 4.73 & 1.74 & 1.13 \\
\hline 30 & 29.3 & 1.92 & 12.13 & 18.62 & 4.74 & 1.55 & 1.74 \\
\hline 60 & 31.3 & 2.22 & 12.47 & 20.09 & 4.98 & 1.44 & 2.43 \\
\hline 150 & 39.9 & 2.37 & 13.53 & 20.16 & 5.60 & 1.50 & 3.57 \\
\hline 330 & 41.9 & 2.68 & 13.76 & 19.17 & 6.59 & 1.90 & 3.38 \\
\hline
\end{tabular}

${ }^{1 /}$ Estimated contents based on regression equations (Figures $2 \mathrm{a}-2 \mathrm{~g}$ ) for the 120 DAE assessment time; ${ }^{2 / E s t i m a t e d ~ r o o t s ~ y i e l d ~ p e r ~ p l a n t ~ i n ~ k g ~}$ based on regression equation (Figure $2 \mathrm{~g}$ ) for the 120 DAE assessment time

highest $\mathrm{K}$ concentration (12.1 $\mathrm{g} \mathrm{kg}^{-1}$ ), while the roots had the lowest $\mathrm{K}$ concentration $\left(1.2 \mathrm{~g} \mathrm{~kg}^{-1}\right.$ of $\left.\mathrm{K}\right)$.

Just like $\mathrm{K}$, contents of $\mathrm{Ca}$ (Figure 2d) and $\mathrm{Mg}$ (Figure 2e) in the leaf as a function of the harvest dates were described by the quadratic model for all $\mathrm{N}$ dosages. Contents of $\mathrm{Ca}$ found in the cassava leaves of cultivar Aciolina varied from 17.66 to $20.16 \mathrm{~g} \mathrm{~kg}^{-1}, 120$ DAE. Between 184 and 200 DAE occurred the highest concentration of $\mathrm{Ca}$ in the leaves for $\mathrm{N}$ dosages, especially in the plants grown with $\mathrm{N}$ dosage of $150 \mathrm{~kg} \mathrm{ha}^{-1}$, which presented the highest Ca level, of $27.92 \mathrm{~g} \mathrm{~kg}^{-1}, 200$ DAE. On the 300th DAE, Ca levels decreased for all levels of $\mathrm{N}$ fertilization, in the range of 11.18 to $16.08 \mathrm{~g} \mathrm{~kg}^{-1}$.

Considering the sufficiency limits established by Raij (2011), from 5 to $15 \mathrm{~g} \mathrm{~kg}^{-1}$, leaf Ca contents in cultivar Aciolina were found within or outside the established range, 120 DAE (Table 2), as well as in the other dates for the $\mathrm{N}$ dosages assessed (Figure 2d). It can also be seen that the $\mathrm{N}$ dosage of $330 \mathrm{~kg} \mathrm{ha}^{-1}$ affected negatively the uptake of $\mathrm{Ca}$, with levels of this nutrient found in the leaves below those observed in the $\mathrm{N}$ dosages of 60 and $150 \mathrm{~kg} \mathrm{ha}^{-1}$. This is probably due to the competition between the $\mathrm{Ca}^{+}$and $\mathrm{NH}_{4}{ }^{+}$cations by the plant's uptake sites or by high $\mathrm{NH}_{4}^{+}$concentration, which favors the move of $\mathrm{Ca}$ from the roots zone. Similar behavior was observed in other crops such as sunflower (LOBO; GRASSI FILHO; BRITO, 2011) and cotton (CARVALHO et al., 2001), where the contents diminished as $\mathrm{N}$ dosages increased.

On the 120th DAE the foliar Mg contents varied from 4.73 to $6.59 \mathrm{~g} \mathrm{~kg}^{-1}$ for all $\mathrm{N}$ dosages (Table 2), within or above the sufficiency range of $2-5 \mathrm{~g} \mathrm{~kg}^{-1}$ established by Raij (2011). The period of maximum concentration was between 219 and 241 DAE and varied from 5.56 to $8.25 \mathrm{~g} \mathrm{~kg}^{-1}$ of $\mathrm{Mg}$ in the leaves, with increased $\mathrm{N}$ dosages (Figure 2e). Without $\mathrm{N}$, the plant presented a reduction of $\mathrm{Mg}$ concentration in the leaf that ranged from 10 to $48 \%$ relating to the $\mathrm{N}$ dosages of 30 and $330 \mathrm{~kg} \mathrm{ha}^{-1}$, respectively. On the 300th DAE, the plants showed from $\mathrm{Mg}$ levels in the range of 5.36 to $7.14 \mathrm{~g} \mathrm{~kg}^{-1}$, according to the $\mathrm{N}$ dosages. The high $\mathrm{Mg}$ contents found in the leaves can be explained by the higher demand of this nutrient to accomplish the chlorophyll synthesis, which presents $\mathrm{N}$ and $\mathrm{Mg}$ in its structure as a result of the greater availability of $\mathrm{N}$ stimulating the growth, in the dosages studied (RIBEIRO; PEREIRA, 2011).

The sulfur contents in the cassava leaves of cultivar Aciolina increased linearly according to the harvest dates for all $\mathrm{N}$ dosages (Figure 2f). On the 120th DAE, the $\mathrm{S}$ content for all levels of $\mathrm{N}$ studied was found below the sufficiency limits, between 2 and $4 \mathrm{~g} \mathrm{~kg}^{-1}$, as established by Raij (2011), and from 2.6 to $3.0 \mathrm{~g} \mathrm{~kg}^{-1}$, according to Martinez, Carvalho and Souza (1999). For the N dosages of 0 and $330 \mathrm{~kg} \mathrm{ha}^{-1}$, the highest contents of $\mathrm{S}$ were found, of 1.74 and $1.90 \mathrm{~g} \mathrm{~kg}^{-1}$, respectively. The highest $\mathrm{S}$ concentration for the dosage of $0 \mathrm{~kg} \mathrm{ha}^{-1}$ was probably due to its lower dilution. Although high roots production was observed, it could be seen that the availability of $S$ was limiting, if we consider the sufficiency limits suggested by the authors.

According to Stipp and Casarin (2010), along with nitrogen, sulfur is found in all functions and processes that are part of the plant's growth, from ionic absorption to RNA and DNA functions, including the hormone control for the cells growth and differentiation. According to these authors, the existence of $\mathrm{N}: \mathrm{S}$ ratio requires an adequate balance in the plants' nutrition regarding these elements. Adequate nitrogen fertilization levels, for low $\mathrm{S}$ contents in the soil, can lead to the accumulation of non-protein forms of $\mathrm{N}$, resulting in an inefficient use of the nitrogen fertilizers and low quality of the products. In the present study it was found that the larger availability of $\mathrm{N}$ resulted in higher yields, indicating that $\mathrm{S}$ did not interfere with roots production and its influence is possibly more related to the roots quality.

Roots production per plant was positively affected by the planting dates for all levels of $\mathrm{N}$ fertilization (Figure 2g). Daily increments of roots production per 
plant varied from 0.004 to $0.0145 \mathrm{~kg}$, especially with $\mathrm{N}$ dosage of $150 \mathrm{~kg} \mathrm{ha}^{-1}$, which determined the highest root mass gains in all harvest dates. The maximum yield obtained for all dosages studied was $3.57 \mathrm{~kg}$ per plant, corresponding to the harvest of $300 \mathrm{DAE}$ with $\mathrm{N}$ dosage of $150 \mathrm{~kg} \mathrm{ha}^{-1}$ (Table 2). These results correspond to the estimated average yields of $55.75 \mathrm{Mg} \mathrm{ha}^{-1}$, much higher than the average yields found in the state of Roraima (13.31 $\mathrm{Mg} \mathrm{ha}^{-1}$ ), and Brazil (13,74 $\mathrm{Mg} \mathrm{ha}^{-1}$ )(INSTITUTO BRASILEIRO DE GEOGRAFIA E ESTATÍSTICA, 2013). This therefore suggests that the plants were in nutritional balance for all levels of $\mathrm{N}$ cover fertilization.

The stimulation of the plant's growth by higher $\mathrm{N}$ availability was found by Cardoso Júnior et al. (2005) in two cassava varieties, Sergipe and Lisona. According to the author, both the aerial portion of the plant and the tubers increased linearly as a function of increased $\mathrm{N}$ dosages. So, the increased aerial portion was not sufficient to affect negatively the balance between the development of the aerial portion and the roots, which would provide a reduction in crop yields. According to Xie et al. (2011), soil fertilization, particularly with $\mathrm{N}$, increases significantly its photosynthetic rate, providing more roots production.

The sequence of nutrients concentration in the cassava cultivar Aciolina had the following descending order: $\mathrm{N}>\mathrm{Ca}>\mathrm{K}>\mathrm{Mg}>\mathrm{P}>\mathrm{S}$. These results are different from those found by Parry et al. (2005), namely, $\mathrm{K}>\mathrm{N}>\mathrm{Ca}>\mathrm{Mg}>\mathrm{P}>\mathrm{S}$, and by Rodríguez et al. (2009), namely, $\mathrm{N}>\mathrm{K}>\mathrm{Ca}>\mathrm{P}>\mathrm{Mg}>\mathrm{S}$. It is possible that the disagreements found are due to the availability of nutrients in the soil. In the case of this study, the soil acidity was corrected by dolomitic limestone, increasing the availability of $\mathrm{Ca}$ and $\mathrm{Mg}$ in the sorption complex, thus affecting the availability of $\mathrm{K}$.

Pearson's correlation coefficients ( $r$ ) for the roots average production per plant as a function of the variables relating to the levels of macronutrients are shown in Table 3. Except for sulfur, the other macronutrients showed a positive correlation with roots production, regardless of the date of assessment.

According to Table 3, the contents of N, P, K and $\mathrm{Mg}$, as measured 120 DAE, were more closely correlated with the roots yields per plant, differently from $\mathrm{Ca}$, which although significant had a low correlation. Such low correlation of calcium is explained by its low mobility, not easily redistributed in the plant. Following 210 DAE a close relation between the leaf Ca contents and the tubers production was found, indicating that the mobilization of this nutrient changes according the plant's age. It is possible that such effect is connected with the quality of the roots harvested later, which is not suitable for consumption as a food.
The existence of non-significant and negative coefficients of correlation between the foliar S levels in the periods of assessment with roots production per plant suggests that the translocation of this nutrient stored in the collected leaves was not determinant for this variable. The negative correlation of $\mathrm{S}$ with roots production may be related to the production of the cysteine amino acid (MENGEL; KIRKBY, 1987), resulting in the immobilization of other macronutrients, such as nitrogen.

Table 3 - Linear correlation coefficients between the roots average production per plant at $330 \mathrm{DAE}$ and the means of the variables of macronutrients concentrations in the leaves of cassava cultivar Aciolina, in five assessment dates

\begin{tabular}{lccccc}
\hline \multirow{2}{*}{ Variables } & \multicolumn{5}{c}{ Assessment dates (DAE) } \\
\cline { 2 - 6 } & 120 & 150 & 180 & 240 & 300 \\
\hline $\mathrm{N}$ & $0.86^{* * *}$ & $0.75^{* * *}$ & $0.77^{* * *}$ & $0.78^{* * *}$ & $0.64 * *$ \\
$\mathrm{P}$ & $0.88^{* * * *}$ & $0.88^{* * *}$ & $0.76^{* * *}$ & $0.81^{* * *}$ & $0.89^{* * *}$ \\
$\mathrm{~K}$ & $0.79 * * *$ & $0.90^{* * *}$ & $0.71^{* * *}$ & $0.85^{* * *}$ & $0.86^{* * *}$ \\
$\mathrm{Ca}$ & $0.39^{*}$ & $0.60^{* *}$ & $0.49^{*}$ & $0.80^{* * *}$ & $0.94 * * *$ \\
$\mathrm{Mg}$ & $0.71^{* *}$ & $0.77^{* * *}$ & $0.79^{* * *}$ & $0.71^{* *}$ & $0.75^{* *}$ \\
$\mathrm{~S}$ & $0.16^{\mathrm{ns}}$ & $-0.31^{\mathrm{ns}}$ & $-0.21^{\mathrm{ns}}$ & $-0.74 * *$ & $-0.01^{\mathrm{ns}}$ \\
\hline ns, ${ }^{* * *}, * *, *-$ not significant, significant by the t-test at $0.1,1$ and $5 \%$ \\
probability level, respectively
\end{tabular}

\section{CONCLUSIONS}

1. The uptake of macronutrients by the cassava cultivar Aciolina is affected by assessment times and $\mathrm{N}$ levels;

2. Dosage of nutrients in the leaves at $120 \mathrm{DAE}$ is a good indicator of the nutritional condition of the cassava cultivar Aciolina;

3. Dosages of $\mathrm{N}$ influenced the production of tubers, especially the dosage of $150 \mathrm{~kg} \mathrm{ha}^{-1}$, determining the highest yields per plant;

4. The sequence of nutrients concentrations in the leaves of cassava cultivar Aciolina, $120 \mathrm{DAE}$, presents the following descending order: $\mathrm{N}>\mathrm{Ca}>\mathrm{K}>\mathrm{Mg}>\mathrm{P}>\mathrm{S}$.

\section{ACKNOWLEDGEMENTS}

The authors wish to thank CNPq for the financial support required to carry out the research, and CAPES for granting the scholarship and PRPPG/ UFRR for the support to publication. 


\section{REFERENCES}

AGUIAR, E. B. et al. Efeito da densidade populacional e época de colheita na produção de raízes de mandioca de mesa. Bragantia, v. 70, n. 3, p. 561-569, 2011.

ALBUQUERQUE, J. A. A. et al. Cultivo de mandioca e feijão em sistemas consorciados realizado em Coimbra, Minas Gerais, Brasil. Revista Ciência Agronômica, v. 43, n. 3, p. 532-538, 2012.

ALBUQUERQUE, J. A. A. et al. Interferência de plantas daninhas sobre a produtividade da mandioca (Manihot esculenta). Planta Daninha, v. 26, n. 2, p. 279-289, 2008.

ALVES, A. A. C. Fisiologia da Mandioca. In: SOUZA, L. S.; FARIAS, A. R. N.; MATTOS, P. L. P.; FUKUDA, W. M. G. (Eds.). Aspectos Socioeconômicos e Agronômicos da Mandioca. Cruz das Almas: EMBRAPA Mandioca e Fruticultura Tropical, v. 1. Cap. 7. 2006. 817 p.

ALVES, J. M. A. et al. Avaliação agroeconômica da produção de cultivares de feijão-caupi em consórcio com cultivares de mandioca em Roraima. Revista Agro@ mbiente On-line, v. 3, n. 1, p. 15-30, 2009.

AYOOLA, O. T.; MAKINDE, E. A. Complementary organic and inorganic fertilizer application: influence on growth and yield of cassava/maize/melon intercrop with a relayed cowpea. Australian Journal of Basic and Applied Sciences, v. 1, n. 3, p. 187-192, 2007.

BENEDETTI, U. G. et al. Gênese, química e mineralogia de solos derivados de sedimentos pliopleistocênicos e de rochas vulcânicas básicas em Roraima, norte amazônico. Revista Brasileira de Ciência do Solo, v. 35, p. 299-312, 2011.

CARDOSO JÚNIOR, N. S. et al. Efeito do nitrogênio sobre o teor de ácido cianídrico em plantas de mandioca. Acta Scientiarum Agronomy, v. 27, n. 4, p. 603-610, 2005.

CARVALHO, M. A. C. et al. Uso da adubação foliar nitrogenada e potássica no algodoeiro. Bragantia, v. 3, n. 60, p. 239-244, 2001.

COELHO, R. I. et al. Teores foliares de nutrientes em mudas do abacaxizeiro 'cv. smooth cayenne' em resposta à adubação. Revista de Ciências Agrárias, v. 33, n. 2, p. 173-179, 2010.

CRUZ, L. J.; PELACANI, C. R.; ARAÚJO, W. L. Efeito do nitrato e amônio sobre o crescimento e eficiência de utilização do nitrogênio em mandioca. Bragantia, v. 65, n. 3, p. 467-475, 2006.

DEVIDE, A. C. P. et al. Produtividade de raízes de mandioca consorciada com milho e caupi em sistema orgânico. Bragantia, v. 68, n. 1, p. 145-153, 2009.

FUKUDA, W. M. G. Embrapa pesquisa mandioca para indústrias de amido. ABAM (Associação Brasileira dos produtores de amido de mandioca) Ano III, n. 11, 2005.

IBGE. Instituto brasileiro de geografia e estatística. Levantamento sistemático da produção agrícola. v. 26, n. 4, 2013. 86 p. Disponível em <http://www.ibge.gov.br> acesso em 15 de junho de 2013.

INMET - Instituto Nacional de Meteorologia. Condições de tempo registradas nas capitais de outubro de 2010 a outubro 2011. Disponível em: www.inmet.gov.br/html/ observacoes.php?lnk=Capitais. Acesso: 27 Jan. 2012.

LOBO, T. F.; GRASSI FILHO, H.; BRITO, I. C. A. Efeito do nitrogênio na nutrição do girassol. Bioscience Journal, Uberlândia, v. 27, n. 3, p. 380-391, 2011.

MALAVOLTA, E.; VITTI, G. C.; OLIVEIRA, S. A. de. Avaliação do estado nutricional das plantas: princípios e aplicações. 2.ed. Piracicaba: POTAFOS, 1997. 319p.

MARTINEZ, H. E. P.; CARVALHO, J. G.; SOUZA, R. B. Diagnose foliar. In: RIBEIRO, A. C.; GUIMARÃES, P. T. G. ALVAREZ, V. G. V. (Eds.). Recomendações para uso de corretivos e fertilizantes em Minas Gerais. $5^{\circ}$ Aproximação. Viçosa-MG. 1999. 359 p.

MENGEL, K.; KIRKBY, E. A. Principles of plant nutrition. Bern : International Potash Institute, 1987. 687 p.

MILLS, H. A.; BENTON, J. Plant analysis handbook II. MICROMACRO PUBLISHING. Athens, Georgia. 1996. 422 p.

OLIVEIRA, N. T. et al. Caracterização e identificação de clones de mandioca produzidos em Roraima para o consumo in natura. Revista Agro@mbiente On-line, Boa Vista, v. 05, n. 3, p. 188-193, 2011.

PARRY, M. M. et al. Estado nutricional da mandioca cultivada em diferentes épocas sob cobertura morta e duas adubações. Revista Ciências Agrárias, Belém, n. 43, p. 91-114, 2005.

PEREIRA, G. A. M. et al. Crescimento da mandioca e plantas daninhas em resposta à adubação fosfatada. Revista Ceres, Viçosa, v. 59, n. 5, p. 716-722, 2012.

RAIJ, B. V. Fertilidade do Solo e manejo dos nutrientes. Piracicaba: International Plant Nutrition Institute. 2011. 420 p.

RIBEIRO, K. G; PEREIRA, O. G. Produtividade de matéria seca e composição mineral do capim-tifton 85 sob diferentes doses de nitrogênio e idades de rebrotação. Ciência Agrotécnica, Lavras, v. 35, n. 4, p. 811-816, 2011.

RODRÍGUEZ, Z. F. G. et al. Acumulación total y por órganos de macronutrientes en plantas de yuca (Manihot esculenta Crantz) cv. 'Tempranita' en la altiplanicie de Maracaibo. Revista de la Facultad de Agronomía, Maracay, v. 26, n. 4, p. 470-489, 2009.

SCHWENGBER, D. R.; SMIDERLE, O. J.; MATTIONI, J. O. M. Mandioca: Recomendações para plantio em Roraima. Boa Vista: Embrapa Roraima, 2005. 30 p. (Embrapa Roraima. Circular Técnica, 5)

STIPP, S. R.; CASARIN, V. A importância do enxofre na agricultura. International Plant Nutrition Institute (Informações agronômicas), Piracicaba, n. 129, 2010.

VALLE, T. L. et al. Conteúdo cianogênico em progênies de mandioca originadas do cruzamento de variedades mansas e bravas. Bragantia, v. 63, n. 2, p. 221-226, 2004.

XIE, W. J. et al. Influence of N, P, and $\mathrm{K}$ application on Zea mays $\mathrm{L}$. growth and $\mathrm{Cu}$ and $\mathrm{Pb}$ accumulation. Plant soil environment, v. 57, n. 3, p. 128-134, 2011. 